\title{
Aerosol composition and source apportionment in the Mexico City Metropolitan Area with PIXE/PESA/STIM and multivariate analysis
}

\author{
K. S. Johnson ${ }^{1}$, B. de Foy ${ }^{1, *}$, B. Zuberi ${ }^{1, * *}$, L. T. Molina ${ }^{1, *}$, M. J. Molina ${ }^{1, * * *}$, Y. Xie $^{2}$, A. Laskin ${ }^{3}$, and \\ V. Shutthanandan ${ }^{3}$ \\ ${ }^{1}$ Department of Chemistry and of Earth, Atmospheric and Planetary Sciences, Massachusetts Institute of Technology, \\ Cambridge, MA, USA \\ ${ }^{2}$ Natural Resource Division, Pacific Northwest National Laboratory, Richland, WA, USA \\ ${ }^{3}$ William R. Wiley Environmental Molecular Sciences Lab., Pacific Northwest National Laboratory, Richland, WA, USA \\ *now at: Molina Center for Energy and the Environment, La Jolla, CA, USA \\ *** now at: $\mathrm{GEO}_{2}$ Technologies, Inc., Woburn, MA, USA \\ **** now at: Department of Chemistry and Biochemistry, University of California, San Diego and Scripps Institute of \\ Oceanography, La Jolla, CA, USA
}

Received: 1 March 2006 - Published in Atmos. Chem. Phys. Discuss.: 19 May 2006

Revised: 28 August 2006 - Accepted: 4 October 2006 - Published: 12 October 2006

\begin{abstract}
Aerosols play an important role in the atmosphere but are poorly characterized, particularly in urban areas like the Mexico City Metropolitan Area (MCMA). The chemical composition of urban particles must be known to assess their effects on the environment, and specific particulate emissions sources should be identified to establish effective pollution control standards. For these reasons, samples of particulate matter $\leq 2.5 \mu \mathrm{m}\left(\mathrm{PM}_{2.5}\right)$ were collected during the MCMA-2003 Field Campaign for elemental and multivariate analyses. Proton-Induced X-ray Emission (PIXE), ProtonElastic Scattering Analysis (PESA) and Scanning Transmission Ion Microscopy (STIM) measurements were done to determine concentrations of 19 elements from $\mathrm{Na}$ to $\mathrm{Pb}$, hydrogen, and total mass, respectively. The most abundant elements from PIXE analysis were $\mathrm{S}, \mathrm{Si}, \mathrm{K}, \mathrm{Fe}, \mathrm{Ca}$, and $\mathrm{Al}$, while the major emissions sources associated with these elements were industry, wind-blown soil, and biomass burning. Wind trajectories suggest that metals associated with industrial emissions came from northern areas of the city whereas soil aerosols came from the southwest and increased in concentration during dry conditions. Elemental markers for fuel oil combustion, $\mathrm{V}$ and $\mathrm{Ni}$, correlated with a large $\mathrm{SO}_{2}$ plume to suggest an anthropogenic, rather than volcanic, emissions source. By subtracting major components of soil and sulfates determined by PIXE analysis from STIM total mass measurements, we estimate that approximately $50 \%$ of nonvolatile $\mathrm{PM}_{2.5}$ consisted of carbonaceous material.
\end{abstract}

Correspondence to: K. S. Johnson

(kirstenj@mit.edu)

\section{Introduction}

Atmospheric aerosols are associated with both the causes and consequences of urban air pollution. In addition to their threat to human health (Dockery et al., 1993; Borja-Aburto et al., 1998; Pope et al., 2002; Evans et al., 2002), effects on climate (Kaufman et al., 2002; Penner et al., 2004; Liepert et al., 2004) and visibility (Malm et al., 1994; Eidels-Dubovi, 2002), aerosols affect air quality as heterogeneous reaction sites that alter the trace gas-phase species and may act as sinks of reactive species such as $\mathrm{OH}, \mathrm{O}_{3}, \mathrm{SO}_{2}, \mathrm{HNO}_{3}$, etc. (Schurath and Naumann, 1998; Ravishankara, 1997). Studies show that metals such as $\mathrm{Fe}$ and $\mathrm{Mn}$ may catalyze or otherwise participate in reactions like $\mathrm{SO}_{2}$ oxidation (Chughtai, 1993), and the large surface areas of soot and dust particles have been shown to facilitate heterogeneous reactions (Lary et al., 1999; Grassian, 2001). Because urban particles come from a multitude of sources, anthropogenic to biogenic, they are very diverse in chemical composition and structure (Johnson et al., 2005; Salma et al., 2001). Determining their composition is essential to understanding their properties and reactivity, and hence their environmental effects.

The Mexico City Metropolitan Area (MCMA) is both a complex and valuable case study for atmospheric chemistry due to its unique locality and high pollutant emissions (Molina and Molina, 2002). The MCMA has a population of more than 18 million and encompasses an urban area of about $1500 \mathrm{~km}^{2}$ surrounded by mountains on three sides. Impacts on aerosol pollution in the basin have been studied previously (Raga et al., 1999; Baumgartner et al., 2000),

Published by Copernicus GmbH on behalf of the European Geosciences Union. 
and meteorological conditions during MCMA-2003 were analyzed by de Foy et al. (2005). Particle trajectory simulations have found rapid ventilation of the basin and short residence times on the order of a day or less (de Foy et al., 2006; Fast and Zhong, 1998).

Comprehensive compositional analysis of atmospheric particles may be performed through Proton-Induced X-ray Emission (PIXE), Proton Elastic Scattering Analysis (PESA) and Scanning Transmission Ion Microscopy (STIM). These techniques are appealing for many reasons, among which are their nondestructive natures and high sensitivities (Johansson et al., 1995; Bench et al., 2002). Used in conjunction with the DRUM impactor for particle collection (Cahill and Wakabayashi, 1993), PIXE, PESA, and STIM are well-suited to time-resolved elemental speciation of atmospheric aerosol. In this manuscript, we present the results of these analyses for DRUM samples of $\mathrm{PM}_{2.5}$ collected in the MCMA during the MCMA-2003 Field Campaign in order to apportion particulate emissions sources.

\section{Experimental}

Aerosol samples were collected from 3 April to 4 May at the Centro Nacional de Investigación y Capacitación Ambiental (CENICA), located in a commercial-residential area in southeastern MCMA. Samples were collected onto Teflon strips using a 3-Stage IMPROVED DRUM impactor (UC Davis, CA) in size ranges $1.15-2.5 \mu \mathrm{m}$ (Stage A), 0.34$1.15 \mu \mathrm{m}$ (Stage B), and 0.07-0.34 $\mu \mathrm{m}$ (Stage C) at a fixed flow of 10 SLPM with a rotation rate of $2 \mathrm{~mm}$ per $12 \mathrm{~h}$. PIXE, PESA and STIM analyses were done within several weeks following the MCMA-2003 campaign at the Environmental Molecular Sciences Laboratory (EMSL) at Pacific Northwest National Laboratory (PNNL). Experimental procedures were similar to those reported previously (Shutthanandan et al., 2002) and only briefly described here. Teflon substrates were carefully removed from the impactor and mounted on plastic strips. These strips were then mounted on a special sample holder inside a vacuum chamber which was maintained at approximately $2 \times 10^{-7}$ Torr pressure. A $3.5 \mathrm{MeV}$ proton beam was used for simultaneous PIXE and PESA analyses, while a $0.75 \mathrm{MeV}$ beam was used separately for STIM analysis. PIXE spectra were evaluated by the GUPIX program (Maxwell et al., 1989), and concentrations of elements were determined by calibration to known standards. Elements were fit by their principal spectral lines except for $\mathrm{Pb}$ in which $L_{\alpha}(10.225 \mathrm{eV})$ was used due to $\mathrm{S}$ interference with $M_{\alpha}\left(K_{\alpha}[\mathrm{S}]=2.306 \mathrm{eV} ; M_{\alpha}[\mathrm{Pb}]=2.342 \mathrm{eV}\right)$. Pb concentrations were below detection level. Hydrogen concentrations were calculated from PESA spectra with reference to several Mylar films of known thickness. Total ion mass was calibrated from STIM spectra with several known standards.

\section{Positive matrix factorization}

Multivariate receptor models have been widely used to identify the number of sources and their composition profiles (Hopke, 1991, 2003). The general receptor models can be formulized as a chemical mass balance (CMB) problem in terms of contributions from $p$ independent sources to all chemical species measured in a given sample (Miller et al., 1972; Hopke, 1985, 1991):

$x_{i j}=\sum_{k=1}^{p} g_{i k} f_{k j}+e_{i j}$

where $x_{i j}$ is the $j$-th species concentration measured in the $i$-th sample, $g_{i k}$ is the emitted mass concentration from the $k$-th source to the $i$-th sample, $f_{k j}$ is the $j$-th species mass fraction from the $k$-th source, $p$ is the number of independent sources and $e_{i j}$ is the residual associated with the concentration of the $j$-th species in the $i$-th sample. The corresponding matrix form is:

$\mathbf{X}=\mathbf{G F}+\mathbf{E}$

where $\mathbf{X}$ is a $n \times m$ concentration matrix of $m$ species in all $n$ samples and $\mathbf{E}$ is the residual matrix with the same dimension of $X$. $\mathbf{G}$ is a $n \times p$ source contribution matrix and $\mathbf{F}$ is a $p \times m$ sources composition profile matrix of the $p$ sources.

Unlike the CMB approach, positive matrix factorization (PMF) allows for the determination of the source composition profile and source contribution simultaneously, which do not require a priori knowledge of detailed source composition profiles. Source apportionment is based on the measured ambient data with knowledge of the specific study for interpreting the resolved factors into meaningful sources.

PMF uses non-negativity constraints on the factors to decrease the rotation freedom on the solutions of the factorization. To address the problem associated with the nonoptimum scaling in principle component analysis (PCA), factorization is conducted to minimize the objective function weighted by the uncertainties for the observations. The objective function is defined as:

$Q(\mathbf{E})=\sum_{i=1}^{n} \sum_{j=1}^{m}\left[\frac{e_{i j}}{s_{i j}}\right]^{2}=\sum_{i=1}^{n} \sum_{j=1}^{m}\left[\frac{x_{i j}-\sum_{k=1}^{p} g_{i k} f_{k j}}{s_{i j}}\right]^{2}$

where $s_{i j}$ is an uncertainty estimate of $x_{i j}$ for the $j$-th species in the $i$-th sample. The factorization is solved to minimize the objective function $Q(\mathbf{E})$ with respect to $\mathbf{G}$ and $\mathbf{F}$ while constraining each of the elements in the $\mathbf{G}$ and $\mathbf{F}$ matrices to non-negative values (Paatero and Tapper, 1993). It has been shown that such constrained optimization cannot be solved by direct use of singular value decomposition or eigenvector based methods. Initially the problem was solved iteratively using alternating least squares (Paatero and Tapper, 1993) and now employs a global optimization scheme 
Table 1. PIXE, PESA, and STIM results for Stages A $(1.15-2.5 \mu \mathrm{m}), \mathrm{B}(0.34-1.15 \mu \mathrm{m})$ and C $(0.07-0.34 \mu \mathrm{m})$. Note that PIXE and PESA units are $\mathrm{ng} / \mathrm{m}^{3}$ while STIM units are $\mu \mathrm{g} / \mathrm{m}^{3}$.

\begin{tabular}{|c|c|c|c|c|c|c|c|c|c|c|c|c|}
\hline & \multicolumn{4}{|c|}{$\begin{array}{c}\text { Stage A } \\
1.15-2.5 \mu \mathrm{m}\end{array}$} & \multicolumn{4}{|c|}{$\begin{array}{c}\text { Stage B } \\
0.34-1.15 \mu \mathrm{m}\end{array}$} & \multicolumn{4}{|c|}{$\begin{array}{c}\text { Stage C } \\
0.07-0.34 \mu \mathrm{m}\end{array}$} \\
\hline & ave & $\max$ & $\min$ & error & ave & $\max$ & $\min$ & error & ave & $\max$ & $\min$ & error \\
\hline (ng/m3) & & & & & & & & & & & & \\
\hline $\mathrm{Na}$ & 9.5 & 69.5 & 0 & $30 \%$ & 11.2 & 77.2 & 0 & $26 \%$ & 17.2 & 45.7 & 4.4 & $14 \%$ \\
\hline $\mathrm{Mg}$ & $*$ & (12.7) & 0 & $41 \%$ & 6.3 & 13.9 & 0 & $29 \%$ & 14.9 & 36.7 & 4.2 & $12 \%$ \\
\hline $\mathrm{Al}$ & 25.9 & 77.5 & 5.1 & $8 \%$ & 40.5 & 109.7 & 0 & $6 \%$ & 73.7 & 188.1 & 13.4 & $3 \%$ \\
\hline $\mathrm{Si}$ & 117.4 & 339.5 & 52.0 & $3 \%$ & 130.6 & 311.8 & 20.5 & $2 \%$ & 225.2 & 606.4 & 48.4 & $2 \%$ \\
\hline $\mathrm{P}$ & 5.7 & 21.8 & 0 & $36 \%$ & 8.7 & 30.5 & 0 & $29 \%$ & * & (12.6) & 0 & $38 \%$ \\
\hline S & 688.0 & 1551.6 & 292.7 & $1 \%$ & 957.6 & 1926.7 & 344.5 & $1 \%$ & 98.5 & 313.7 & 14.3 & $3 \%$ \\
\hline $\mathrm{Cl}$ & 19.6 & 56.6 & 4.1 & $18 \%$ & 28.7 & 73.8 & 7.2 & $14 \%$ & 8.6 & 27.1 & 0 & $19 \%$ \\
\hline $\mathrm{K}$ & 108.5 & 252.0 & 28.5 & $3 \%$ & 135.0 & 339.6 & 27.0 & $2 \%$ & 30.7 & 78.3 & 6.0 & $6 \%$ \\
\hline $\mathrm{Ca}$ & 25.4 & 63.2 & 7.6 & $7 \%$ & 51.7 & 104.2 & 12.3 & $4 \%$ & 92.2 & 257.3 & 22.0 & $2 \%$ \\
\hline $\mathrm{Ti}$ & 3.1 & 19.0 & 0 & $23 \%$ & 6.2 & 28.3 & 2.2 & $14 \%$ & 8.3 & 33.1 & 0 & $9 \%$ \\
\hline $\mathrm{V}$ & 3.6 & 82.5 & 0 & $26 \%$ & 4.1 & 64.1 & 0 & $21 \%$ & * & (18.1) & 0 & $62 \%$ \\
\hline $\mathrm{Mn}$ & $*$ & (5.4) & 0 & $37 \%$ & 3.0 & 23.0 & 0 & $20 \%$ & 1.3 & 10.3 & 0 & $28 \%$ \\
\hline $\mathrm{Fe}$ & 29.0 & 72.8 & 14.1 & $4 \%$ & 63.2 & 196.9 & 31.2 & $2 \%$ & 80.3 & 251.7 & 16.4 & $2 \%$ \\
\hline $\mathrm{Ni}$ & $*$ & (14.2) & 0 & $50 \%$ & $*$ & (12.8) & 0 & $41 \%$ & $*$ & $(4.3)$ & 0 & $54 \%$ \\
\hline $\mathrm{Cu}$ & 5.9 & 37.3 & 0 & $14 \%$ & 15.1 & 117.9 & 2.1 & $9 \%$ & 10.0 & 68.5 & 0 & $11 \%$ \\
\hline $\mathrm{Zn}$ & 19.8 & 162.8 & 3.8 & $7 \%$ & 34.6 & 341.2 & 8.5 & $6 \%$ & 13.7 & 82.0 & 2.7 & $9 \%$ \\
\hline As & $*$ & (13.1) & 0 & $36 \%$ & 3.0 & 19.0 & 0 & $31 \%$ & $*$ & (4.1) & 0 & $58 \%$ \\
\hline $\mathrm{Br}$ & * & (11.3) & 0 & $42 \%$ & 3.2 & 32.9 & 0 & $36 \%$ & * & (2.8) & 0 & $37 \%$ \\
\hline Sn & 28.3 & 91.8 & 0 & $31 \%$ & 43.8 & 97.9 & 0 & $23 \%$ & 13.3 & 49.4 & 0 & $35 \%$ \\
\hline $\begin{array}{l}\mathrm{PESA} \mathrm{H} \\
(\mathrm{ng} / \mathrm{m} 3)\end{array}$ & 980.0 & 2405.4 & 165.7 & & 506.6 & 1404.2 & 147.3 & & 66.9 & 197.9 & 21.6 & \\
\hline $\begin{array}{l}\text { STIM } \\
(\mu \mathrm{g} / \mathrm{m} 3)\end{array}$ & 7.05 & 16.96 & 0.68 & & 9.89 & 21.72 & 0.29 & & 3.10 & 7.16 & 1.47 & \\
\hline
\end{tabular}

(Paatero and Tapper, 1994; Paatero, 1997). Details of the algorithm implementation may be found in Hopke (2000) and Paatero (2000).

PMF was applied to PIXE and PESA data to help identify particulate emissions sources in the MCMA. The quality of the variables was determined by both the number of below detection limit values and the signal-to-noise ratio (Paatero and Hopke, 2003). The variable was defined as "bad" and excluded from multivariate receptor modeling when the percentage of below detection and zeros values exceeded $60 \%$ and the signal-to-noise ratio was smaller than 2.5. If only one of the criteria was satisfactory, the variable was defined as "weak" and assigned less weight (Paatero and Hopke, 2003). Error estimates were calculated using a variety of formulas based on analytical uncertainty and detection limit values. The following error estimate strategy, modified on that originally proposed by Polissar et al. (2001), was used in obtaining the final solutions. For determined values, the sum of the analytical uncertainty and one third of the detection limit was used as the estimate of the standard deviation. For non-zero below detection limit values, the value was replaced by half of the detection limit and the detection limit taken as the error estimate. For zero values, half of the minimum detection limit was used as the values and the minimum detection limit was used as the error estimate. The number of PMF factors was determined by trial and error based on the interpretability of the resolved factors, the robustness of the objective functions, and the relative changes in the objective functions with the change of the number of factors (Hopke, 2000).

\section{Chemical composition and emissions sources}

Element concentrations and spectrum fit errors from PIXE analysis (Na, Mg, Al, Si, P, S, Cl, K, Ca, Ti, V, Mn, Fe, Ni, $\mathrm{Cu}, \mathrm{Zn}, \mathrm{As}, \mathrm{Br}, \mathrm{Sn}$ ), hydrogen concentrations from PESA, and total mass from STIM are summarized in Table 1. The statistical error and detection limits derived from the PIXE spectrum fitting procedure were used in PMF analysis; median error values are shown in Table 1. Errors for major elements $(\mathrm{S}, \mathrm{Si}, \mathrm{K})$ were about $5 \%$ while most other elements ranged from $10 \%$ to $50 \%$. Overall uncertainty in mass calibration was $5 \%$ based on measurements of standard materials purchased from MicroMatter, Deer Harbor, WA, USA.

PMF analysis of PIXE and PESA data identified 8 factors in Stage A, 7 in Stage B and 4 in Stage C. Factors were identified by the representative elements, the explained variation matrix and the shape of the source contribution and source composition profiles. Because $\mathrm{S}$ and earth elements appeared in nearly all of the factors, matrix rotation was done by pulling down $\mathrm{S}$ from the soil factors and earth elements from the industrial factors. Figure 1 shows the composition elements and relative contribution of factors within each size category.

\subsection{Sulfate}

Among PIXE measured elements, $\mathrm{S}$ was highest in concentration and surpassed only by $\mathrm{Si}$ in Stage C (Table 1). Single particle analysis and aerosol mass spectrometry (AMS) 


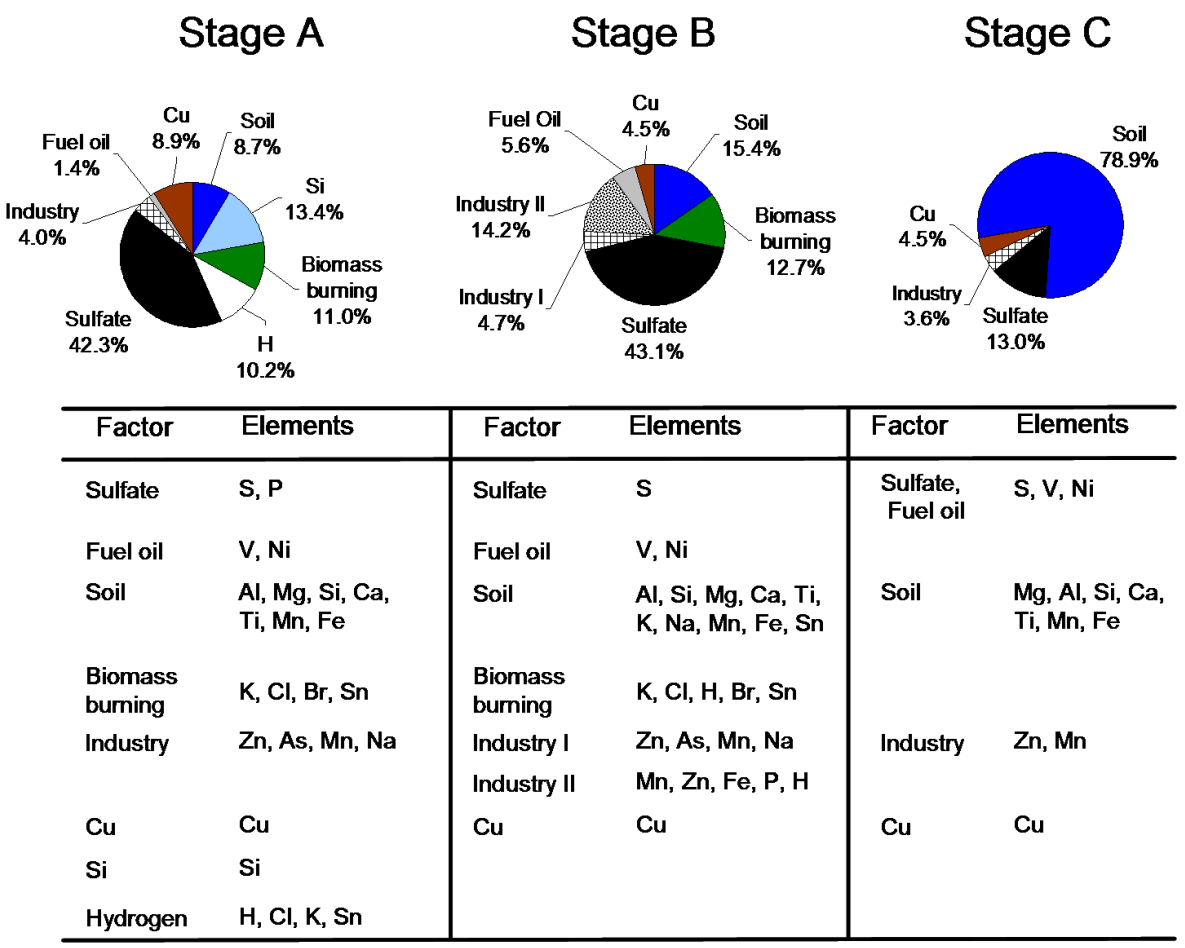

Fig. 1. PMF factors for Stages A, B, and C.

measurements during MCMA-2003 confirm that $\mathrm{S}$ was a major component of $\mathrm{PM}_{2.5}$ and suggest that it was present as ammonium sulfate during the majority of the campaign (Johnson et al., 2005; Salcedo et al., 2005). The relatively high minimum concentration of $\mathrm{S}$ in $\mathrm{PM}_{2.5}\left(0.826 \mu \mathrm{g} / \mathrm{m}^{3}\right.$; the sum of stages $\mathrm{A}, \mathrm{B}, \mathrm{C}$ ) indicates a consistent background of particulate sulfate, most likely formed by aqueous phase $\mathrm{SO}_{2}$ oxidation on a regional, rather than local scale (Salcedo et al., 2005). The influence of the Popocatepetl volcano, $60 \mathrm{~km}$ southeast of Mexico City, on sulfate aerosol production has been the subject of several studies (Moya et al., 2003; Raga et al., 1999), but the role of anthropogenic $\mathrm{SO}_{2}$ emissions remains unclear (see Sect. 4.1.2). In addition, the effects of sulfur-containing fuel and mobile emissions on sulfate formation in the MCMA are not yet well studied.

\subsection{Industry}

Heavy metals appearing in several of the factors suggest industrial emissions. Cu comprises a separate factor in each size range (Fig. 1), perhaps signifying a particular sector or source. The other factors marked by $\mathrm{Zn}, \mathrm{Mn}, \mathrm{Na}$, and As may be a mix of various industrial activities. The two separate factors in Stage B have been labeled Industry I and II for lack of specific information on the activities involved. Zn has been traced to tire and brake wear (Smolders and DeGryse, 2002; Lin et al., 2005); vehicle debris mixed in dust could perhaps explain the Si factor in Stage A which was weakly associated with $\mathrm{Zn}, \mathrm{Mn}$, and $\mathrm{Fe}$, as well as $\mathrm{Al}, \mathrm{K}$, and $\mathrm{Ca}$.
A correlation between $\mathrm{Si}$ and $\mathrm{Zn}$ in Mexico city aerosol was noted by Miranda et al. (1994) but not explained at that time.

The industrial factors reflect individual emissions events rather than consistent patterns. On 9 April, concentrations of $\mathrm{Na}, \mathrm{Mn}, \mathrm{As}$ and $\mathrm{Zn}$ rose sharply during the early morning (0:00-6:00) as shown in Fig. 2a. The sudden increase is clearly distinguishable above the low background levels measured during most of the campaign. In order to ascertain the likely direction of the plume, simulations of particle back-trajectories were performed as described in de Foy et al. (2006). The paths for particle tracers arriving at CENICA at 6:00 (Fig. 2b) show that the air masses during this time came from north/northeast of the MCMA, which is among the more industrial sections of the city. This is corroborated by the fact that this event occurred during a "Cold Surge" episode with wind transport into the basin from the north (de Foy et al., 2006).

Similarly, a sharp increase in fuel oil components $\mathrm{V}$ and $\mathrm{Ni}$ was observed for 10 April (Fig. 3a). The V/Ni ratio of 5.25 is comparable to that found in a study that sourced the metals directly to power plant emissions in the U.S. (Kowalczyk et al., 1982). The maximum $\mathrm{V}$ and $\mathrm{Ni}$ values coincided with a large $\mathrm{SO}_{2}$ plume (97.6 ppb; Fig. 3a) strongly suggesting an anthropogenic, rather than volcanic, emissions source. Particle back-trajectory simulations follow a north/northwest source direction (Fig. 3b) with paths over the location of the Tula power plant located approximately $80 \mathrm{~km}$ north of CENICA. 
(a)
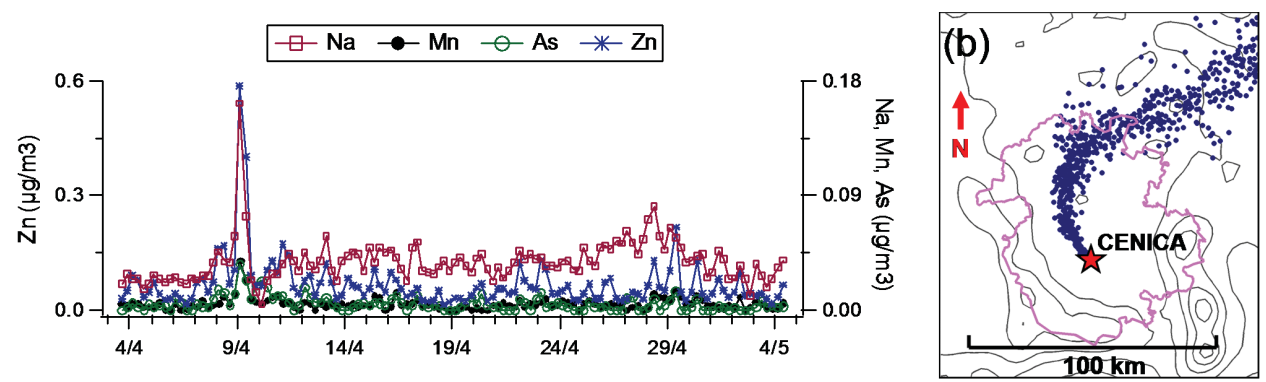

Fig. 2. 9 April industrial emissions: (a) Time series of industrial emissions markers Na, Mn, As, Zn from PIXE analysis and (b) particle cloud back trajectory from CENICA.
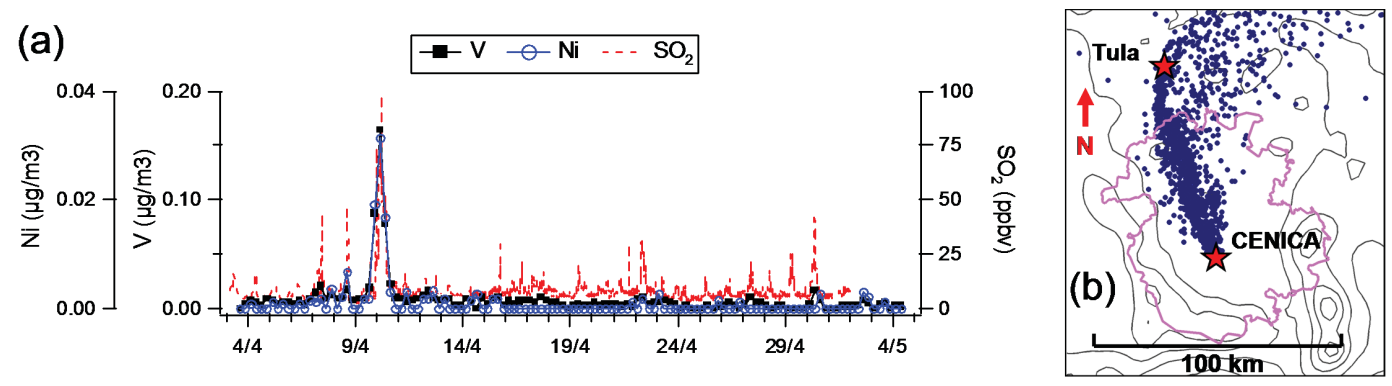

Fig. 3. 10 April emissions: (a) time series of fuel oil components $\mathrm{V}$, Ni shown with $\mathrm{SO}_{2}$ measured at CENICA, and (b) particle back trajectory indicating a north/northwest emissions source.

Various studies have been done on $\mathrm{SO}_{2}$ source emissions in the MCMA. During the rainy season, increased levels have been attributed to the Popocatepetl volcano (Moya et al., 2003). In November 1997, Raga et al. (1999) studied the volcano's impact on sulfate production in Mexico City and identified episodes of high $\mathrm{SO}_{2}$ levels. Because these plumes were independent of $\mathrm{CO}$, it was suggested that they were due to volcanic emissions. Power plants can have high $\mathrm{SO}_{2}$ and low $\mathrm{CO}$ emissions, however (CAM, 2004), and our findings suggest that anthropogenic $\mathrm{SO}_{2}$ emissions may have an important impact on MCMA air quality that has been previously overlooked. This has been supported by the recent study of Miranda et al. (2005) which found evidence of anthropogenic sources for particulate $\mathrm{S}$ in the MCMA.

\subsection{Biomass burning}

Factors composed of elements $\mathrm{K}, \mathrm{Cl}, \mathrm{Sn}, \mathrm{Br}$, and $\mathrm{H}$ indicate biomass burning where $\mathrm{H}$ is a tracer for organic compounds (Miranda et al., 1996; Malm et al., 1994). Potassium salts, such as $\mathrm{KCl}$, are commonly found in particulate emissions from burning vegetation (Li et al., 2003; Hand et al., 2005). The time series for $\mathrm{K}, \mathrm{Cl}$, and organic $\mathrm{H}$ are shown in Fig. 4; organic $\mathrm{H}$ is calculated as the amount in excess of ammonium sulfate $\left([\mathrm{H}]_{\text {total }}-0.25[\mathrm{~S}]\right)$ assuming loss of volatile compounds (nitrates, water) in the vacuum chamber during PIXE/PESA analysis. The most volatile organics are also assumed to have been lost in vacuum. A section of hydrogen

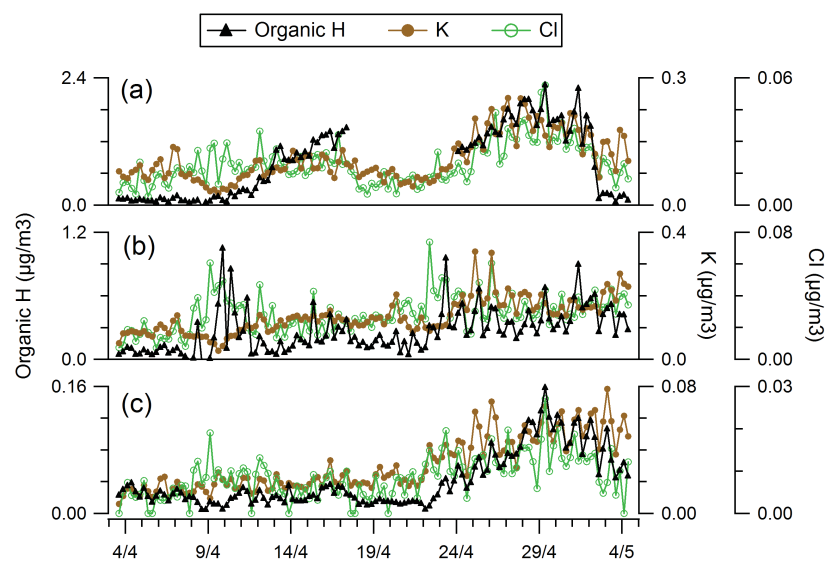

Fig. 4. Elemental markers of biomass burning, $\mathrm{K}, \mathrm{Cl}$ and organic $\mathrm{H}$ for (a) Stage A, (b) Stage B, and (c) Stage C. A portion of organic $\mathrm{H}$ data is missing in (a) due to a complication with PESA analysis; see text.

data is missing in Stage A (Fig. 4a) because minor damage to the substrate caused partial distortion of PESA spectra. A separate biomass burning factor was not identified in Stage $\mathrm{C}$ (Fig. 1) because it was not possible to separate $\mathrm{H}$ from the soil elements.

Bravo et al. (2002) analyzed the MCMA air quality impact of wildfires in, and immediately surrounding the Mexico 


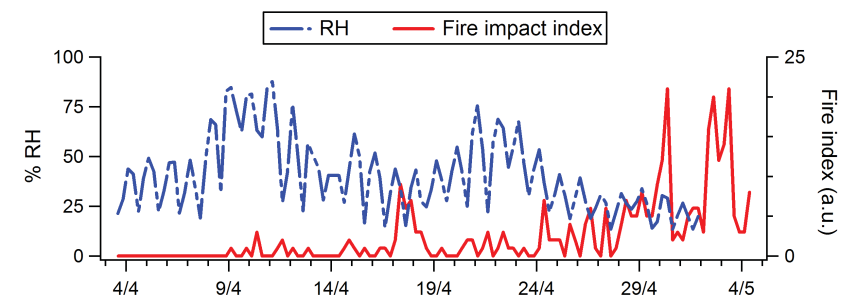

Fig. 5. Relative humidity (6-h average) measured at CENICA and fire impact index in the MCMA during MCMA-2003.

City basin from 1992 to 1997 . They report a correlation between fire emissions and concentrations of TSP (total suspended particulates) and $\mathrm{PM}_{10}$ (particulate matter $<10 \mu \mathrm{m}$ in diameter). Our findings suggest that longer range transport of larger wildfire emissions may also impact the urban area. We have calculated forward particle trajectories based on MODIS (Moderate Resolution Imaging Spectroradiometer) fire detection products (Justice et al., 2002) in Mexico during the time of the campaign. MODIS data at $1 \mathrm{~km}$ resolution was aggregated to a $12 \mathrm{~km}$ grid, with one particle released per MODIS pixel for 2-day simulations starting every $6 \mathrm{~h}$ of the campaign. Particle concentrations within a $36 \mathrm{~km}$ grid cell over CENICA were calculated as a proxy fire impact index. The number of fires increased noticeably after 22 April with decreased relative humidity $(R H)$ (Fig. 5), after which concentrations of biomass burning indicators, $\mathrm{K}$ and $\mathrm{Cl}$, steadily increased (Fig. 4). An increase in organics was measured by AMS during this period as well (Salcedo et al., 2006). We note a strong correlation between biomass burning markers and Stage $C(0.07-0.34 \mu \mathrm{m})$ soil elements, which could be the result of a common source direction and/or dry conditions accompanying the fires that facilitated re-suspension and transport of fine soil dust (Gaudichet et al., 1995). The correlation between organic $\mathrm{H}$ and earth elements $\left(R^{2}=0.76\right.$, Stage C) eliminates ambiguity introduced by the fact that $\mathrm{K}$ is a component of both smoke and soil.

\subsection{Soil}

Soil factors represented by common earth elements were identified in each of the three particle size categories. Figures $6 \mathrm{a}-\mathrm{c}$ show that the concentrations of soil components $\mathrm{Si}, \mathrm{Ca}, \mathrm{Al}, \mathrm{Fe}, \mathrm{Mg}$, and Ti clearly track one another throughout the campaign. Soil particles followed a diurnal pattern with the highest concentrations in the morning when winds were typically calm and mixing heights were low (de Foy et al., 2005). An anti-correlation between fine soil particles and wind speed may be explained through dilution effects.

Overall increases in soil concentration may be observed from approximately 15-18 April and after 23 April during periods of lower $R H$. Figure 5 shows 6 -h average $R H$ values measured at CENICA (see Sect. 4.1.3 for discussion of the fire impact index in Fig. 5). From the $15-18^{\text {th }}$ the aver-

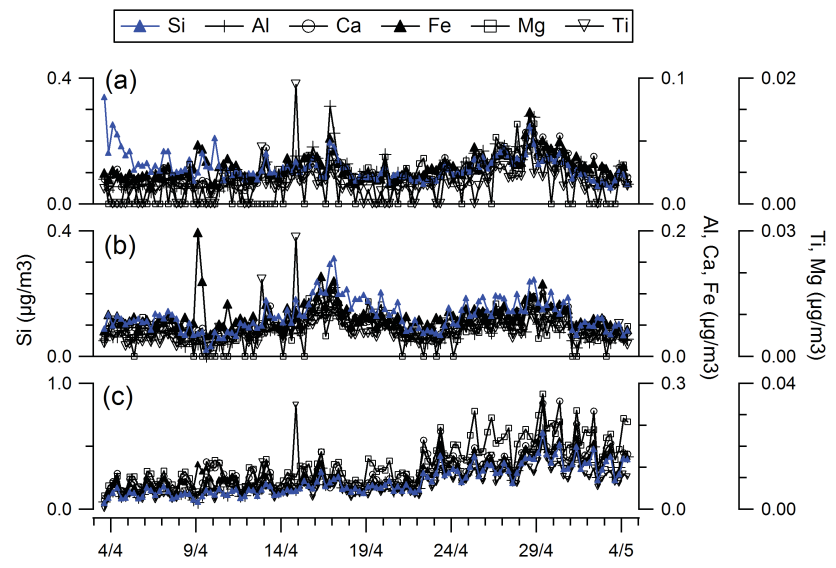

Fig. 6. Time series of soil factors (a) Stage A, 1.15-2.5 $\mu \mathrm{m}$; (b) Stage B, 0.34-1.15 $\mu \mathrm{m}$; (c) Stage C, 0.07-0.34 $\mu \mathrm{m}$.

age daily temperature measured at CENICA rose from 20.1 ${ }^{\circ} \mathrm{C}$ to $23.5{ }^{\circ} \mathrm{C}$ while the average $R H$ dropped from $52.1 \%$ to $19.4 \%$. An increase in soil concentration is particularly clear for Stage C particles $(0.07-0.34 \mu \mathrm{m})$ after the $23^{r d}$, suggesting longer range transport from outside the basin, probably facilitated by dry conditions. The period following 23 April was classified as an " $\mathrm{O}_{3}$ North" event (de Foy et al., 2005) with particle back-trajectories passing up the Rio Balsas valley and over Toluca to the west/southwest of the Mexico City basin (de Foy et al., 2006). Along with the low $\mathrm{Na}$ and $\mathrm{Cl}$ concentrations $\left(\leq 0.1 \mu \mathrm{g} / \mathrm{m}^{3}\right)$, this evidence disfavors the dry Texcoco lake bed to the north of CENICA as the dominant source of soil particles as discussed in other studies (Moya et al., 2004). Soil composition during this period was similar to that of paved/unpaved roads and/or tezontle soil based on a fugitive dust emissions reported by Vega et al. (2001). Element ratios calculated from $\mathrm{PM}_{2.5}$ average concentrations were: $\mathrm{Fe} / \mathrm{Si}=0.365$ (compared with $0.231,0.219,0.345$ for paved, unpaved roads, and tezontle soil, respectively), $\mathrm{Ca} / \mathrm{Si}=0.358(0.295,0.534,0.363)$, $\mathrm{Na} / \mathrm{Si}=0.080(0.008,0.123,0.041)$, and $\mathrm{Al} / \mathrm{Si}=0.296(0.306$, $0.288,0.460$ ). The $\mathrm{PM}_{2.5}$ concentration of dust/soil particles may be estimated through the common metal oxides of earth elements (e.g. $\mathrm{SiO}_{2}, \mathrm{Al}_{2} \mathrm{O}_{3}, \mathrm{Fe}_{2} \mathrm{O}_{3}$ ) as demonstrated by Malm et al. (1994):

$[$ Soil $]=2.20[\mathrm{Al}]+2.49[\mathrm{Si}]+1.63[\mathrm{Ca}]+2.42[\mathrm{Fe}]+1.94[\mathrm{Ti}]$

We have applied this equation as a first approximation for the $\mathrm{PM}_{2.5}$ soil component. The resulting concentrations were, Stage $A=0.47 \mu \mathrm{g} / \mathrm{m}^{3}$, Stage $B=0.66 \mu \mathrm{g} / \mathrm{m}^{3}$, and Stage $\mathrm{C}=1.08 \mu \mathrm{g} / \mathrm{m}^{3}$. While soil comprised $6.6 \%$ of Stage A (with reference to STIM measurements) and $6.7 \%$ of Stage B, it contributed more than one-third (35.0\%) of Stage C mass. 


\section{STIM}

The contribution of each stage to total $\mathrm{PM}_{2.5}$ mass $=20.04 \mu \mathrm{g} / \mathrm{m}^{3}(100 \%)$ as measured by STIM was as follows: Stage $A=7.05 \mu \mathrm{g} / \mathrm{m}^{3}$ (35\%), Stage $\mathrm{B}=9.89 \mu \mathrm{g} / \mathrm{m}^{3}$ (49\%), and Stage $\mathrm{C}=3.10 \mu \mathrm{g} / \mathrm{m}^{3}(15 \%)$. The volatile particulate components including nitrates, water, and a portion of organics are assumed to have been lost in the vacuum chamber during analysis. Mass measured by STIM may therefore be apportioned to sulfates, soil, heavy metals, black carbon, and non-volatile organics. Carbon was not directly measured in our samples. However, by subtracting sulfates and soil from the STIM total we may infer that about $50 \%$ of $\mathrm{PM}_{2.5}$ mass was carbonaceous, including both organic and black carbon. Figure 7 shows the approximate contribution of each component by mass; heavy metals were negligible. Sulfates accounted for approximately $40 \%$ of STIM in Stages A and B, and $13 \%$ in Stage C. As previously discussed, soil comprised less than $10 \%$ in the two larger stages, but more than one-third in the smallest size range. The relative distribution of non-volatile $\mathrm{PM}_{2.5}$ aerosol components shown in Fig. 7 is qualitatively consistent with that of total $\mathrm{PM}_{2.5}$ approximated by Salcedo et al. (2006) using a combination of AMS, aethelometer, Tapered Element Oscillating Microbalance (TEOM), and PIXE data. This analysis found that nearly two-thirds of $\mathrm{PM}_{2.5}$ was carbonaceous (organics $=54.6 \%$, black carbon $=11.0 \%$ ), followed by sulfate $(10.3 \%)$, nitrate $(10.0 \%)$, soil $(6.9 \%)$ and chloride $(0.8 \%)$. Further analysis of PESA hydrogen as tracer for organic compounds is in progress. The results are yet to be published.

\section{Comparison with previous studies}

Variability in season, meteorology, and pollutant emissions complicate comparisons among different MCMA field studies. However, we offer several comments for better understanding of aerosol spatial and temporal variability. We note that Salcedo et al. (2006) discussed the composition of total $\mathrm{PM}_{2.5}$ during MCMA-2003 with reference to previous studies.

Our data are best compared to other PIXE and X-ray Fluorescence (XRF) studies (Miranda et al., 1992, 1994, 1996, 2004; Chow et al., 2002; Díaz et al., 2002; Aldape et al., 2005) which also pertain to non-volatile species. Among these works, several (Miranda et al., 1994; 1996, 2004; Díaz et al., 2002; Aldape et al., 2005) applied multivariate analysis and identified sources similar to those featured here. Biomass burning emissions were not included or only briefly mentioned in these studies, which may be partially because marker elements $\mathrm{K}$ and $\mathrm{Cl}$ have multiple sources including soil. In our case, the PESA hydrogen marker for organic aerosol exhibited a strong correlation with $\mathrm{K}$ and $\mathrm{Cl}$ to form

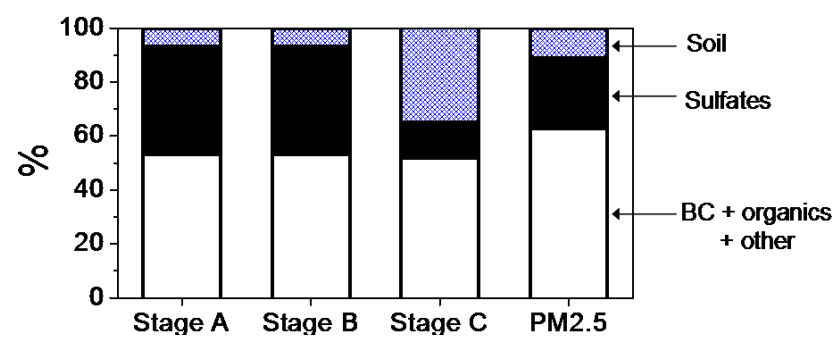

Fig. 7. Speciation of STIM mass into major components for Stages $\mathrm{A}, \mathrm{B}, \mathrm{C}$, and $\mathrm{PM}_{2.5}$ (sum of all stages). Volatile components including nitrates, water, and a fraction of organics were assumed to have been lost in vacuum prior to analysis.

a separate factor even though a connection between organics and soil was suggested in Stage C.

In terms of average concentrations, our data are similar to those of Chow et al. (2002) taken in March 1997 at Cerro de la Estrella (CES), located less than $2 \mathrm{~km}$ southeast of our site at CENICA. Comparable concentrations were observed for major elements $\mathrm{S}$ (average $=1.79 \mu \mathrm{g} / \mathrm{m}^{3}$ and $1.74 \mu \mathrm{g} / \mathrm{m}^{3}$ for $\mathrm{PM}_{2.5}$ in this study and Chow et al., respectively) and $\mathrm{K}$ (average $=0.27 \mu \mathrm{g} / \mathrm{m}^{3}$ and $0.30 \mu \mathrm{g} / \mathrm{m}^{3}$ ). Chow et al. (2002) found higher levels of soil elements $(\mathrm{Si}, \mathrm{Fe}, \mathrm{Ca})$ at the CES site than our measurements, but they also discussed large variations in geological material attributed to variability in fugitive dust emissions. Multiple studies have shown that heavy metals tend to be higher in northern sections of the city (Miranda et al., 1994, 2004) near industrial sources. This is consistent with our observation of overnight industrial emission episodes with a northern source direction.

Mobile sources are generally underestimated by this approach to source apportionment since soot and organic aerosols associated with traffic emissions are not directly detected by PIXE/PESA/STIM or XRF. Miranda et al. (1996) identified a factor related to traffic emissions through $\mathrm{Pb}$ and $\mathrm{Br}$, but levels of these gasoline additives have generally declined over time. Vega et al. (1997) employed a comprehensive chemical mass balance (CMB) receptor model including PIXE data, elemental and organic carbon, sulfates, and nitrates. They reported that vehicle emissions were responsible for over $40 \%$ of $\mathrm{PM}_{2.5}$ in Mexico City; it should be noted that samples were taken near major roadways in 19891990 before installation of catalytic converters and the discontinued use of leaded fuel. Aldape et al. (2005) used PIXE data in conjunction with gaseous pollutants $\mathrm{CO}, \mathrm{NO}_{\mathrm{x}}$, and $\mathrm{SO}_{2}$ in 2003-2004 to conclude that automotive sources were an important contribution to $\mathrm{PM}_{2.5}$. Measurements during MCMA-2003 confirm that mobile sources were important sources of organic aerosol (Jiang et al., 2005; Marr et al., 2006; Salcedo et al., 2006), a fraction of which was detected by PESA. 


\section{Conclusions}

Size-segregated samples of $\mathrm{PM}_{2.5}$ were collected during MCMA-2003 for compositional analysis and source apportionment. Concentrations of elements $\mathrm{Na}$ to $\mathrm{Pb}$, hydrogen, and total mass were measured by PIXE, PESA, and STIM analyses. Among PIXE measured elements, $\mathrm{S}$ was highest in concentration for particles of diameter $0.34-2.5 \mu \mathrm{m}$ whereas Si was highest within size range $0.07-0.34 \mu \mathrm{m}$. PMF factors within each size category indicate that the major sources were industrial emissions, soil, and biomass burning. Wind trajectories suggest that industrial emissions came from large northern point sources. A correlation between $\mathrm{V}$ and $\mathrm{Ni}$ - elements related to fuel oil burning - and a large $\mathrm{SO}_{2}$ plume indicate emissions from the Tula refinery to the north of the MCMA. Particulate biomass burning markers show an impact on the MCMA basin from regional wildfire emissions. Biomass burning episodes were also associated with increased fine soil particle concentrations, which likely resulted from longer range transport of particles from the southwest area outside the basin. Assuming that the major components of non-volatile $\mathrm{PM}_{2.5}$ during MCMA-2003 were sulfates, soil, black carbon and organics, STIM total mass measurements suggest that approximately $50 \%$ of nonvolatile $\mathrm{PM}_{2.5}$ consisted of carbonaceous compounds.

Acknowledgements. We would like to thank the many MCMA2003 participants for their contribution to this research through many helpful discussions. In particular, we are grateful to $\mathrm{J}$. Jimenez, K. Dzepina and D. Salcedo, and to M. Zavala for comments on the manuscript. This research was funded by the Mexican Metropolitan Environmental Commission, National Science Foundation (ATM-0528227) and Department of Energy (Award DE-FG02-05ER63980). A portion of this research was done at the Environmental Molecular Sciences Laboratory, a national scientific user facility sponsored by the Department of Energy's Office of Biological and Environmental Research and located at Pacific Northwest National Laboratory. PNNL is operated by the U.S. Department of Energy by Battelle Memorial Institute under contract No. DE-AC06-76RL0 1830.

Edited by: C. E. Kolb

\section{References}

Aldape, F., Flores, J. M., Flores, J. A., Retama-Hernández, A., and Rivera-Hernández, O.: Elemental composition and source identification of $\mathrm{PM}_{2.5}$ particles collected in downtown Mexico City, Int. J. PIXE, 15, 263-270, 2005.

Baumgartner, D., Raga, G. B., Kok, G., Ogren, J., Rosas, I., Báez, A., and Novakov, T.: On the evolution of aerosol properties at a mountain site above Mexico City, J. Geophys. Res., 105, $22243-$ 22 253, 2000.

Bench, G., Grant, P. G., Ueda, D., Cliff, S. S., Perry, K. D., and Cahill, T. A.: The use of STIM and PESA to measure profiles of aerosol mass and hydrogen content, respectively across my- lar rotating drums Impactor samples, Aerosol Sci. Technol., 36, 642-651, 2002.

Borja-Aburto, V. H., Castillejos, M., Gold, D. R., Bierzwinski, S., and Loomis, D.: Mortality and Ambient Fine Particles in Southwest Mexico City, 1993-1995, Environ. Health Perspect., 106, 849-855, 1998.

Bravo, A. H., Sosa, E. R., Sánchez, A. P., Jaimes, P. M., and Saavedra, R. M. I.: Impact of wildfires on the air quality of Mexico City, 1992-1999, Environ. Poll., 117, 243-253, 2002.

Cahill, T. A. and Wayakabashi, P.: Compositional analysis of sizesegregated aerosol samples, ACS Adv. Chem. Ser., 232, 211228, 1993.

CAM (Comisión Ambiental Metropolitana): Inventario de Emisiones 2002 de la Zona Metropolitana del Valle México, Mexico, 2004.

Chow, J. C., Watson, J. G., Edgerton, S. A., and Vega, E.: Chemical composition of $\mathrm{PM}_{2.5}$ and PM10 in Mexico City during winter 1997, Sci. Tot. Environ., 287, 177-201, 2002.

Chughtai, A. R., Brooks, M. E., and Smith, D. M.: Effect of metal oxides and black carbon (soot) on $\mathrm{SO}_{2} / \mathrm{O}_{2} / \mathrm{H}_{2} \mathrm{O}$ reaction systems, Aerosol Sci. Technol., 19, 121-132, 1993.

de Foy, B., Caetano, E., Magana, V., Zitácuaro, A., Cárdenas, B., Martínez, A. P., Retama, A., Ramos, R., Reyes, R., Sosa, G., Molina, L. T., and Molina, M. J.: Mexico City basin wind circulation during the MCMA-2003 field campaign, Atmos. Chem. Phys., 5, 2267-2288, 2005, http://www.atmos-chem-phys.net/5/2267/2005/.

de Foy, B. , Varela, J. R., Molina, L. T., and Molina, M. J.: Rapid ventilation of the Mexico City basin and regional fate of the urban plume, Atmos. Chem. Phys., 6, 2321-2335, 2006, http://www.atmos-chem-phys.net/6/2321/2006/.

Díaz, R. V., Aldape, F., and Flores, J. M.: Identification of airborne particulate sources, of samples collected in Ticomán, Mexico, using PIXE and multivariate analysis, Nucl. Instr. Meth. Phys. Res. B., 189, 249-253, 2002.

Dockery, D. W., Pope III, C. A., Xu, X., Spengler, J. D., Ware, J. H., Faye, M. E., Ferris, B. G., and Speizer, F. E.: An association between air pollution and mortality in six U.S. cities, N. Engl. J. Med., 329, 1753-1759, 1993.

Eidels-Dubovoi, S.: Aerosol impacts on visible light extinction in the atmosphere of Mexico City, Sci. Tot. Environ., 287, 213-220, 2002.

Evans, J., Levy, J., Hammitt, J., Burgoa, C. S., and Castillejos, M.: Health benefits of air pollution control, Chapter 4, in: Air Quality in the Mexico City Megacity Megacity: An Integrated Assessment, Kluwer Academic, 2002.

Fast, J. D. and Zhong, S.: Meteorological factors associated with inhomogeneous ozone concentrations within the Mexico City basin, J. Geophys. Res., 103, 18 927-18 946, 1998.

Gaudichet, A., Echalar, F., Chatenet, B., Quisefit, J. P., Maingre, G., Cachier, H., Buat-Menard, P., Artaxo, P., and Maenhaut, W.: Trace elements in tropical African savanna biomass burning aerosols, J. Atmos. Chem., 22, 19-39, 1995.

Grassian, V.: Heterogeneous uptake and reaction of nitrogen oxides and volatile organic compounds on the surface of atmospheric particles including oxides, carbonates, soot and mineral dust: implications for the chemical balance of the troposphere, Int. Rev. Phys. Chem., 20, 467-548, 2001.

Hand, J. L., Malm, W. C., Laskin, A., Day, D., Lee, T., Wang, C., 
Carrico, C., Carrillo, J., Cowin, J. P., Collett Jr, J., and Iedema. M. J.: Optical, physical and chemical properties of tar balls observed during the Yosemite Aerosol Characterization Study, J. Geophys. Res., 110, D21210, doi:10.1029/2004JD005728, 2005.

Hopke, P. K.: A Guide to Positive Matrix Factorization, EPA Workshop Proceedings, Materials from the Workshop on UNMIX and PMF as Applied to $\mathrm{PM}_{2.5}$, 14-16 February , 2000.

Hopke, P. K.: Receptor Modeling for Air Quality Management, Elsevier, New York, 1991.

Hopke, P. K.: Receptor Modeling in Environmental Chemistry, Wiley \& Sons, New York, 1985.

Hopke, P. K.: Recent development in receptor modeling, J. Chemom, 17, 255-265, 2003.

Jiang, M., Marr, L. C., Dunlea, E. J., Herndon, S. C., Jayne, J. T., Kolb, C. E., Knighton, W. B., Rogers, T. M., Zavala, M., Molina, L. T., and Molina., M. J.: Vehicle fleet emissions of black carbon, polycyclic aromatic hydrocarbons, and other pollutants measured by a mobile laboratory in Mexico City, Atmos. Chem. Phys., 5, 3377-3387, 2005,

http://www.atmos-chem-phys.net/5/3377/2005/.

Johansson, S., Campbell, J. L., and Malmqvist, K. G.: ParticleInduced X-Ray Emission Spectrometry (PIXE), John Wiley \& Sons, Inc., New York, 1995.

Johnson, K. S., Zuberi, B., Molina, L. T., Molina, M. J., Iedema, M. J., Cowin, J. P., Gaspar, D. J., Wang, C., and Laskin, A.: Processing of soot in an urban environment: Case study from the Mexico City Metropolitan Area, Atmos. Chem. Phys., 5, 30333043, 2005,

http://www.atmos-chem-phys.net/5/3033/2005/.

Justice, C. O., Giglio, L., Korontzi, S., Owens, J., Morisette, J. T., Roy, D., Descloitres, J., Alleaume, S., Petitcolin, F., and Kaufman, Y.: The MODIS fire products, Rem. Sens. Environ., 83, 244-262, 2002.

Kaufman, Y. J., Tanré, D., and Boucher, O: A satellite view of aerosols in the climate system, Nature, 419, 215-223, 2002.

Kowalczyk, G. S., Gordon, G. E., and Rheingrover, S. W.: Identification of atmospheric particulate sources in Washington, D.C., using chemical element balances, Environ. Sci. Technol., 16, 7990, 1982.

Lary, D. J., Shallcross, D. E., and Toumi, R.: Carbonaceous aerosols and their potential role in atmospheric chemistry, J. Geophys. Res., 104, 15 929-15 940, 1999.

Li, J., Pósfai, M., Hobbs, P. V., and Buseck, P.: Individual aerosol particles from biomass burning in southern Africa: 2. Compositions and aging of inorganic particles, J. Geophys. Res., 108(D13), doi:10.1029/2002JD002310, 2003.

Liepert, B. G., Feichter, J., Lohmann, U., and Roeckner, E.: Can aerosols spin down the water cycle in a warmer and moister world?, Geophys. Res. Lett., 31, L06207, doi:10.1029/2003GL019060, 2004.

Lin, C., Chen, S., Huang, K, Hwang, W., Chien, G. C., and Lin, W: Characteristics of metals in nano/ultrafine/fine/coarse particles collected beside a heavily trafficked road, Environ. Sci. Technol., 39, 8113008122, 2005.

Malm, W. C., Sisler, J. F., Huffman, D., Eldred, R. A., and Cahill, T. A.: Spatial and seasonal trends in particle concentration and optical extinction in the United States, J. Geophys. Res., 99, 13471370, 1994.

Marr, L. C., Dzepina, K., Jimenez, J. L., Reisen, F., Bethel, H. L.,
Arey, J., Gaffney, J. S., Marley, N. A., Molina, L. T., and Molina, M. J.: Sources and transformations of particle-bound polycyclic aromatic hydrocarbons in Mexico City, Atmos. Chem. Phys., 6, 1733-1745, 2006, http://www.atmos-chem-phys.net/6/1733/2006/.

Maxwell, J. A., Campbell, J. L., Teesdale, W. J.: The GUELPH PIXE software package, Nucl. Instr. Meth. B, 43, 218-230, 1989.

Miller, M. S., Friedlander, S. K., and Hidy, G. M.: A chemical element balance for the Pasadena aerosol, J. Colloid Interface Sci., 39, 165-176, 1972.

Miranda, J., Andrade, E., López-Suárez, A., Ledesma, R., Cahill, T. A., and Wakabayashi, P. H.: A receptor model for atmospheric aerosols from a southwestern site in Mexico City, Atmos. Environ., 30, 3471-3479, 1996.

Miranda, J., Barrera, V. A., Espinosa, A. A., Galindo, O. S., Meinguer, J: PIXE analysis of atmospheric aerosols in Mexico City, X-Ray Spectrom., 34, 315-319, 2005.

Miranda, J., Barrera, V. A., Espinosa, A. A., Galindo, O. S., NúñezOrosco, Montesinos, R. C., Leal-Castro, A., and Meinguer, J. PIXE analysis of atmospheric aerosols from three sites in Mexico City, Nucl. Instr. Meth. B, 219-220, 157-160, 2004.

Miranda, J., Cahill, T. A., Morales, J. R., Aldape, F., Flores, J. M., and Díaz, R. V.: Determination of elemental concentrations in atmospheric aerosols in Mexico City using proton induced x-ray emission, proton elastic scattering, and laser absorption, Atmos. Environ., 28, 2299-2306, 1994.

Miranda, J., Morales, J. R., Cahill, T. A., Aldape, F., and Flores, J. M.: A study of elemental contents in atmospheric aerosols in Mexico City, Atmósfera, 5, 95-108, 1992.

Molina, M. J. and Molina, L. T. (Eds.): Air Quality in the Mexico Megacity: An Integrated Assessment, Kluwer Academic, 2002.

Moya, M., Castro, T., Zepeda, M., and Baez, A.: Characterization of size-differentiated inorganic composition of aerosols in Mexico City, Atmos. Environ., 37, 3581-3591, 2003.

Moya, M., Grutter, M., and Báez, A.: Diurnal variability of sizedifferentiated inorganic aerosols and their gas-phase precursors during January and February of 2003 near downtown Mexico City, Atmos. Environ, 38, 5651-5661, 2004.

Paatero, P.: Least squares formulation of robust non-negative factor analysis, Chemom. Intell, Lab. Syst., 37, 23-35, 1997.

Paatero, P.: User's Guide for Positive Matrix Factorization programs PMF2 and PMF3, 2000.

Paatero, P. and Hopke, P. K.: Discarding or downweighting highnoise variables in factor analytic models, Anal. Chim. Acta, 490, 277-289, 2003.

Paatero, P. and Tapper, U.: Analysis of different modes of factor analysis at least squares fit problems, Chemom. Intell. Lab. Syst., 18, 183-194, 1993.

Paatero, P. and Tapper, U.: Positive matrix factorization: A nonnegative factor model with optimal utilization of error estimates of data values, Environmetrics, 5, 111-126, 1994.

Penner, J. E., Dong, Xiquan, and Chen, Yang: Observational evidence of a change in radiative forcing due to the indirect aerosol effect, Nature, 427, 231-234, 2004.

Polissar, A. V., Hopke, P. K., and Poirot, R. L.: Atmospheric aerosol over Vermont: Chemical composition and sources, Environ. Sci Technol., 35, 4604-4621, 2001.

Pope, C. A., Burnett, R. T., Thun, M. J., Calle, E. E., Krewski, D., Ito, K., and Thurston, G. D.: Lung cancer, cardiopulmonary mor- 
tality, and long-term exposure to fine particulate air pollution, J. Am. Med. Assoc., 287(9), 1132-1141, 2002.

Raga, G. B., Kok, G. L., Baumgardner, D., Báez, A., and Rosas, I.: Evidence for volcanic influence on Mexico City aerosols, Geophys. Res. Lett., 26, 1149-1152, 1999.

Ravishankara, A. R.: Heterogeneous and multiphase chemistry in the troposphere, Science, 276, 1058-1065, 1997.

Salcedo, D., Onasch, T. B., Dzepina, K., Canagaratna, M. R., Zhang, Q., Huffman, J. A., DeCarlo, P. F., Jayne, J. T., Mortimer, P., Worsnop, D. R., Kolb, C. E., Johnson, K. S., Zuberi, B., Marr, L. C., Volkamer, R., Molina, L. T., Molina, M. J., Cardenas, B., Bernabé, R. M., Márquez, C., Gaffney, J. S., Marley, N. A., Laskin, A., Shutthanandan, V., Xie, Y., Brune, W., Lesher, R., Shirley, T., and Jimenez, J. L.: Characterization of ambient aerosols in Mexico City during the MCMA-2003 campaign with Aerosol Mass Spectrometry: results from the CENICA Supersite, Atmos. Chem. Phys., 6, 925-946, 2006, http://www.atmos-chem-phys.net/6/925/2006/.

Salma, I., Maenhaut, W., Zemplén-Papp, É., Záray, G.: Comprehensive characterization of atmospheric aerosols in Budapest, Hungary: physicochemical properties of inorganic species, Atmos. Environ., 35, 4367-4378, 2001.
Schurath, U. and Naumann, K. H.: Heterogeneous processes involving atmospheric particulate matter, Pure Appl. Chem., 70, 1353-1361, 1998.

Shutthanandan, V., Thevuthasan, S., Disselkamp, R., Stroud, A., Cavanagh, A., Adams, E. M., Baer, D. R., Barrie, L. A., Cliff, S. S., Jimenez-Cruz, M., and Cahill, T. A.: Development of PIXE, PESA and transmission ion microscopy capability to measure aerosols by size and time, Nucl. Instr. Meth. B, 189, 284-288, 2002.

Smolders, E. and DeGryse, F.: Fate and effect of zinc from tire debris in soil, Environ. Sci. Technol., 36, 3706-3710, 2002.

Vega, E., García, I., Apam, D., Esther Ruiz, M., and Barbiaux, M.: Application of a chemical mass balance receptor model to respirable particulate matter in Mexico City, J. Air Waste Manage. Assoc., 47, 524-529, 1997.

Vega, E., García, I., Apam, D., Esther Ruiz, M., and Barbiaux, M.: Application of a chemical mass balance receptor model to respirable particulate matter in Mexico City, J. Air Waste Manage. Assoc., 47, 524-529, 1997.

Vega, E., Mugica, V., Reyes, E., Sanchez, G., Chow, J. C., Watson, J. G.: Chemical composition of fugitive dust emitters in Mexico City, Atmos. Environ., 35(23), 4033-4039, 2001. 